\title{
Institutionen som arena för skapandet av sexuell identitet. Samtal från ett särskilt ungdomshem
}

\author{
CAROLINA ÖVERLIEN
}

\begin{abstract}
Syftet med denna samtalsanalytiska studie är att studera hur institutionen kan vara en arena för skapandet av sexuell identitet, genom att analysera tal om sexualitet vid ett särskilt ungdomshem för unga kvinnor, 14 - 20 år. Studien visar hur frägan om sexualitet genomsyrar arbetet $i$ vardagen på institutionen och fungerar som en organisatorisk princip. Studien visar vidare hur personalen talar om de omhändertagna unga kvinnorna som asexuella och som offer för sexuella övergrepp.
\end{abstract}

\section{Bakgrund}

Varje år tvångsomhändertas ett stort antal ungdomar enligt lagen om vård av unga (LVU). Studier visar att omhändertagande och placering av barn och ungdomar i Sverige är ett socialt fält omgivet av problem såsom frekventa återfall i samma destruktiva livsmönster som innan placering, hög frekvens av avbrott av placering och problematisk kontakt med biologiska föräldrar och fos-

Carolina Överlien är fil.dr. vid Tema Barn, Linköpings universitet och är verksam vid Rädda Barnen, Stockholm. terföräldrar (Levin 1997, Sallnäs et al. 2004, Andersson 2005, Socialstyrelsen 2006b).

År 2004 placerades 984 barn och ungdomar på särskilda ungdomshem, med Statens Institutionsstyrelse (SiS) som huvudman (Knutsdotter Vanström et al. 2005). ${ }^{1}$ Att

1 När ett omhändertagande sker av ett barn eller ungdom kan placeringen ske på familjehem, HVB (hem för vård eller boende), eller särskilda ungdomshem. När man använder ordet institution brukar man referera till HVB eller särskilda ungdomshem. När jag använder ordet institution i denna artikel refererar jag dock endast till särskilda ungdomshem, eftersom min studie enbart innefattar denna form av boende. 
samhället omhändertar ungdomar har varit en fråga som främst rört pojkar (att vara "vanartig" var historiskt sett förbehållet pojkar, se Sundkvist 1994). I dag ser vi dock en storleksmässigt ökande grupp flickor och unga kvinnor som omhändertas av samhället. Gruppen omhändertagna unga kvinnor i åldern 15-17 år ökade med 33 procent mellan åren 2000-2004 (Socialstyrelsen 2000, 2005). Socialstyrelsens rapport (2006a) om individ- och familjeomsorg konkluderar att det under perioden 1995-2004 har skett en markant ökning av tonårsflickor (13-17 år) som blir omedelbart omhändertaga, och menar att »det finns anledning att speciellt följa utvecklingen för flickor, särskilt som det finns flera tecken på en problematisk situation för dem" (s. 26).

I ett internationellt perspektiv ökar antalet flickor som hamnar inför ungdomsdomstolar. Det amerikanska forskarparet Chesney-Lind och Shelden (1998) menar att antalet anhållna unga kvinnor ökade med 60 procent mellan åren 1988 och 1997. Omhändertagna barn och ungdomar upplever sig ofta som marginaliserade och inte lyssnade på (Cederborg \& Karlsson 2001, Osvaldsson 2002). Svensk och internationell forskning har funnit att det finns brister rörande barns möjlighet att göra sin röst hörd i domstolsprocesser om tvångsvård (Mattsson 2002, Boylan \& Ing 2005).

Internationell forskning har också funnit att kriterierna för omhändertagande varierar beroende på kön, och att kriterier såsom antal sexualpartners nästan uteslutande används för unga kvinnor (Chesney-Lind \& Shelden 1998, Hudson 1989, Shoemaker 1984). Även svensk forskning visar att flickor omhändertas av andra skäl än pojkar, där flickornas norm-avvikande sexualitet är en viktig aspekt i förhandlingsprocessen om omhändertagande, i motsats till pojkarna vars sexualitet sällan omnämns (Schlytter 1999, 2000, Andersson 1993, 1996). Andersson $(1993,1996)$ fann vid en genomgång av missbruksmottagningen Maria Ungdoms journaler att flickornas sexuella erfarenheter beskrevs på ett utförligt sätt som avvikande och destruktiv, medan pojkarnas sexuella beteende inte diskuteras. Litteraturen om prostitution har framförallt fokuserat på flickor och kvinnor. Det är ett problem när två av tre ungdomar med erfarenhet av att sälja sexuella tjänster var pojkar i en undersökning från Oslo. Detta diskuteras av Hegna och Pedersen (2005) i deras studie om ungdomar under 18 år som säljer sex. Hegna och Pedersen menar att det finns könsbundna föreställningar om pojkars och flickors sexualitet som bidrar till att osynliggöra kunskap om pojkar och prostitution, vilket också medför att de inte får den hjälp de behöver.

De tre kriterierna för tvångsomhändertagande av ungdomar, "drogmissbruk", "kriminalitet" och "socialt nedbrytande beteende", används också olika beroende på ungdomarnas kön. Genom att studera SiS egen statistik finner man att 70 procent av 15-åriga flickor som placeras på särskilda ungdomshem har ett "socialt nedbrytande beteende«, där bl.a. en destruktiv sexualitet och "vagabondage" innefattas, som placeringsorsak (en ungdom kan dock ha flera placeringsorsaker). Dessa kriterier används sällan eller aldrig i relation till pojkar.

Att olika kriterier används för pojkar och flickor är inte nytt ur ett historiskt perspektiv (Odem 1995). Ericsson (1997) menar att 
omhändertagandet av flickor på 1950-talet i Norge är tydligt förankrat i föreställningar om flickors kroppar och sexualitet och behovet av kontroll av det avvikande och destruktiva. År 1977 kom "Skå-Gustav" ut med sin bok om flickor på glid, där han benämnde omhändertagna flickor som "sexualflickor" (Jonsson 1977). Sunesson (1992) visar hur flickor placerade på institution på 1960-talet definierades primärt utifrån sin problematiska sexualitet. Lundström och Sallnäs (2003) menar att moralen hos de enskilda individerna genomsyrade 1902 års barnavårdslagstiftning och att åtgärderna historiskt sett har sett så olika ut beroende på ungdomens kön, att man kan tala om ett pojkåtgärdssystem respektive flickåtgärdssystem.

Vad innebär det för institutionsvärlden att antal flickor som är föremål för omhändertagande ökar? Både svenska och utländska forskare som har studerat flickor på institution menar att än idag är institutionerna byggda och strukturerade för att passa pojkar snarare än flickor. Unga kvinnor ses som problematiska eftersom de inte passar in i den institutionella ramen. Nya problem och dilemman uppkommer när man placerar unga kvinnor i en behandlingsram som av tradition är manlig (Robinson 1994, Andersson 1998, 2000). Flickor anses "svårare" att arbeta med, deras problem "djupare», och de anses vara i större behov av skydd (Hilte \& Claezon 2005, Andersson 1998, Baines \& Alder 1996). Det Goffman (1983) kallade för "totala institutioner", där kontroll och disciplin är grundpelare, är helt enkelt inte anpassade för flickor som snarare är definierade som offer än förövare. Och häri ligger en av utmaningarna för institutionsvården - att behandla flickor som primärt ses som offer i en ram som är bestraffande i sin form.

En annan fråga som innebär utmaningar för institutionsvården, är frågan om sexualitet. En av de frågor jag därför fann intressant att belysa utifrån de problem jag såg att personalen på ett särskilt ungdomshem hade, var hur sexuell identitet skapas. Hur talar personalen om varandra i relation till kön och sexualitet och hur talar personalen om de omhändertagna unga kvinnornas sexualitet? Om sexualitet är en viktig aspekt $i$ omhändertagandet av unga kvinnor, hur talar man då om deras sexualitet när de kommer till ungdomshemmet?

I denna artikel kommer jag att visa hur personalen diskursivt skapar sexuell identitet, trots intentionen att skapa en zon fri från sexualitet där de omhändertagna unga kvinnorna kan få "vilau. Jag kommer vidare visa att personalen talar om de unga kvinnornas sexualitet på två olika sätt: som ickeexisterande genom att tala om dem som asexuella barn, och som icke-existerande genom att tala om dem som offer för sexuella övergrepp. Jag kommer också att diskutera och försöka förstå den rationalitet som ligger bakom ett sådant resonemang.

\section{Metod}

Sommargården, ett av de få särskilda ungdomshem endast för flickor, ligger utanför en mellanstor svensk stad i ett naturskönt område, långt från alla storstadens faror. Institutionen består av fem avdelningar som var och en tar emot sex unga kvinnor. Denna studie har fokuserat på två av dessa avdelningar: en låst som tar emot unga kvin- 
nor med allvarliga psykosociala problem från den övre åldersgruppen (17-20 år) och en låsbar som tar emot unga kvinnor med mindre allvarliga psykosociala problem från den lägre åldersgruppen (14-16 år). På institutionens område finns även en skola där majoriteten av de omhändertagna unga kvinnorna går.

Behandlingsmetoden på avdelningen med 14-16-åringar är, enligt personalen, familjeterapi och miljöterapi. Behandlingsmetoden på avdelningen för 17-20-åringar är miljöterapi. Det fanns dock ingen enhetlig linje i hur personalen definierade dessa behandlingsmetoder. Utbildningsnivån på behandlingsassistenterna varierar, men är generellt låg (för en diskussion om institutionspersonals definitioner av behandlingsmetoder och deras utbildningsnivå, se Sallnäs 2000).

Elva unga kvinnor bodde på de två avdelningarna som min studie fokuserar på, och 19 behandlingsassistenter arbetade där. Alla valde att ingå i min studie. I rekryteringen av personal kvoteras män, vilket innebär att personalgruppen består av hälften män och hälften kvinnor. På grund av att avdelningen för 17-20-åringar är låst och tar emot unga kvinnor med allvarliga psykosociala problem var personaltätheten högre än på avdelningen för 14-16-åringar. Detta resulterar i fler vikarier och extraanställda, och även i en i genomsnitt yngre personalgrupp. Under vintern 2000 tillbringade jag totalt åtta veckor på Sommargården. För att kunna upprätthålla kontakt med min familj och min institution så delades tiden upp i tvåveckorsperioder, d.v.s. jag bodde på Sommargården i två veckor, var därifrån i två veckor, o.s.v. En gång under varje två- veckorsperiod besöktes jag av min handledare under två dagar. Det var också då som de flesta intervjuer genomfördes. Jag bodde till en början på institutionen med de unga kvinnorna och efter hand i en egen lägenhet, och tog i så stor utsträckning som möjligt del av de vardagliga sysslorna på avdelningen. Jag observerade personalens dagliga arbete, lyssnade noga på samtal om de unga kvinnorna och observerade interaktionen mellan personal och de unga kvinnorna. Observationerna användes framförallt för att fånga situationer som anknöt till flickornas utsatthet för sexuella övergrepp när samtalen och situationerna faktiskt ägde rumistället för att personalen berättade om dem efter att de hade skett. Ett exempel på en sådan situation är när en ung kvinna har rymt och kommer tillbaka till institutionen med poliseskort i dålig fysisk och psykiskt kondition. Personalen utgår då ifrån att den unga kvinnan har varit utsatt för sexuella övergrepp, men är osäkra på hur de ska hantera problemet. När en sådan situation uppstod samlade jag till en gruppintervju med den berörda personalstyrkan samma dag eller dagen efter. Efter gruppintervjun genomförde jag även individuella intervjuer med berörd personal. Totalt genomfördes fem gruppintervjuer och 29 individuella intervjuer. Jag genomförde även fem fokusgruppintervjuer med de unga kvinnorna (för en genomgång av fokusgruppsmetoden, se Morgan 1996). Mitt material består därmed primärt av individuella intervjuer och gruppintervjuer, men också av etnografisk data.

Intervjuerna var semi-strukturerade, reflexiva i sin form (Hydén 2000) med öppna frågeställningar såsom: „Hur kan 
vi förstå den här situationen?" och »Vad menar du har hänt och hur kan ni hantera det?« Målet var att få personalen att reflektera kring vilka situationer som skapade problem och dilemman i deras vardagliga arbete med flickor som varit utsatta för sexuella övergrepp. Intervjuerna spelades in på band och transkriberades. Först gjordes en grov transkription och sedan valdes delar av materialet ut (styrt av forskningsfrågan) som sedan fintranskriberades. Nivån av transkription styrdes av den analys som gjordes, och är därmed teori-driven (Ochs 1979). Analysarbetet startar vid insamlingen av data. Transkriptionsprocessen bör därför betraktas som en form av analys och produkten, d.v.s. utskrifterna, som tolkad (Riessman 1997).

\section{Sexuell identitet som organisatorisk princip}

I den metadiskurs som rådde vid institutionen och som presenterades för mig som utomstående såg man alla de unga kvinnorna som offer för sexuella övergrepp. I intervjuerna framkom att behandlingsassistenterna hade en bred definition av sexuella övergrepp, som inkluderade prostitution, att ha sex med äldre män, att ha sex när den unga kvinnan är påverkad av alkohol eller droger, och att som tvångsomhändertagen ha sex med någon på första träffen (se Hydén \& Överlien 2005). Avvikande åsikter fanns dock, som behandlingsassistenten Frank som menar att "det har varit en och annan genom åren" som varit utsatta för sexuella övergrepp. Det fanns också en problematik runt komplexiteten i att bedöma om en händelse ska definieras som ett sexuellt övergrepp eller ej (se Överlien \& Hydén 2003). Trots den dominerande uppfattningen att alla de unga kvinnorna varit utsatta i något sammanhang och vid någon tidpunkt i deras liv, menade personalen att man undvek samtal om sexuella övergrepp, eftersom det ansågs alltför svårt och känsligt att tala om. Samtal om sexualitet och relaterade frågor såsom kropp och sexuella handlingar var inte en del av behandlingsplanen. När dessa frågor togs upp var det ett resultat av ett enskilt sporadiskt initiativ, oftast initierat av skolsköterskan, och handlade då framför allt om somatiska frågor såsom menstruation och hur man undviker graviditet. Att sexualitet är svårt att tala om med utsatta flickor på institution, konstateras i Statens Institutionsstyrelses egen tidning Sistone, som ägnar ett temanummer åt ämnet, med titeln »Den svåra balansgången« (3/2005). En socialpedagog som intervjuas i tidningen menar att "det är viktigt att tala om sex med utsatta flickor på institution. De behöver prata för att förlåta sig själva, men personalen drar sig för samtalen av oro för att göra ont värre. Då lämnas flickorna utan hjälp» (s. 3).

Tidigt i fältarbetet fann jag dock att sexualitet, på en implicit nivå, genomsyrade det vardagliga arbetet, och fungerade därmed som en organisatorisk princip. Heterosexualitet togs förgivet, och institutionsramen var tydligt heteronormativ. Sommargården byggdes endast för flickor, med det syftet att man ville undvika frågor som rör sexualitet. Trots det spelar alltså sexualiteten en avgörande roll, både i omhändertagandet och som organisatorisk princip på institutionen. Även Hilte och Claezon (2005) 
fann i deras studie om flickor och pojkar på särskilda ungdomshem, att behandlingspersonalens föreställningar om flickor och pojkars sexualitet bygger på ett heteronormativt tänkande och på stereotypt könade kategoriseringar. De menar att "flickors handlingar tolkas mot bakgrund av den stereotypa bilden av den fallna och omoraliska kvinnan, medan pojkarnas handlingar problematiseras mot bakgrund av en stereotyp mansroll som handlar om att vara stark och självsäker i relation till det motsatta könet" (ibid s. 44).

Sexualiteten genomsyrade det vardagliga arbetet både i relation till de omhändertagna flickorna, men också i relation till personalen. Som nämnts tidigare könskvoterar Sommargården sin personal, vilket innebär att hälften av personalen är män och hälften kvinnor. Flera kvinnor i personalen uttrycker sitt missnöje med att ha manlig personal, men menar ändå att de behövs för sin kroppsliga styrkas skull. I en individuell intervju med behandlingsassistenten Tina ställer jag frågan hur hon ser på den manliga personalen.

\section{Excerpt I.}

Deltagare: Tina, behandlingsassistent (T), och Carolina Överlien (C)

\begin{tabular}{lll}
\hline I & $T$ & $\begin{array}{l}\text { Vi är ju så vansinnigt rädda här (.) att } \\
\text { killarna ska göra ska gå för långt som } \\
\end{array}$ \\
& $\begin{array}{l}\text { när vi anställer nya unga killar så är vi ju } \\
\text { jättenoga att tjata på dom så där }\end{array}$ \\
\hline 2 & C & mm \\
\hline 3 & T & $\begin{array}{l}\text { Och vi (.) den kvinnliga personalen har } \\
\text { ju verkligen den manliga personalen } \\
\end{array}$ \\
\hline 4 & C & under kontroll \\
\hline
\end{tabular}

Tina uttrycker en stark rädsla att den manliga personalen "ska gå för långt", och detta gäller speciellt nyanställd, ung, manlig personal. I intervjuer med personalen beskrevs manlig sexualitet som aggressiv och explosiv. Som en följd av detta synsätt antog den kvinnliga personalen rollen som kontrollanter av manlig personal och deras beteende. För att undvika att de omhändertagna unga kvinnorna skulle anklaga den manliga personalen för övergrepp, och för att den manliga personalens beteende skulle kunna kontrolleras av den kvinnliga personalen, var alltid en behandlingsassistent av kvinnligt kön närvarande i rummet. Både manlig och kvinnlig personal uttryckte att de var överens om denna implicita regel, eftersom den "skapade trygghet".

I en individuell intervju med behandlingsassistenten Karin talar vi om hur man som manlig personal bör tänka när man arbetar med omhändertagna tjejer.

\section{Excerpt 2.}

Deltagare: Karin, behandlingsassistent (K), Carolina Överlien (C), och Margareta Hydén (M)

\begin{tabular}{lll}
\hline I & K & $\begin{array}{l}\text { Det är ju så generellt att som manlig } \\
\text { personal så får man ju ha ett visst (.) } \\
\text { avstånd så (.) det kan ju misstolkas utav } \\
\text { flickorna också }\end{array}$ \\
\hline 2 & M & $\begin{array}{l}\text { Det är så ja (.) och det behöver man } \\
\text { inte tänka på som kvinna då }\end{array}$ \\
\hline 3 & K & $\begin{array}{l}\text { Nej utifrån hur jag tänker själv eller hur } \\
\text { jag känner själv }\end{array}$ \\
\hline
\end{tabular}

Karin menar att det är viktigt att den manliga personalen behåller ett visst fysiskt avstånd till flickorna. Ett skäl till detta är

Carolina Överlien: Institutionen som arena för skapandet av sexuell identitet. 
att förhindra att den manliga personalen skulle utsätta flickorna för övergrepp, men också, som Karin betonar, för att inte den fysiska närheten ska »misstolkas utav flickorna». När jag frågar om detta är något man behöver tänka på som kvinnlig behandlingsassistent, menar Karin att man inte behöver hålla ett fysiskt avstånd till flickorna som kvinna. Att en kvinnlig behandlingsassistent skulle kunna känna sexuell lust till en tjej ses inte som en möjlighet, och inte heller att den fysiska närheten en kvinnlig behandlingsassistent har till en omhändertagen tjej skulle kunna "misstolkas». På Sommargården ska kvinnlig personal företräda en normal, hälsosam heterosexualitet, och därmed vara goda förebilder för flickorna.

Det är inte alla i personalgruppen som är överens om att den rigida könsuppdelningen är bra. Behandlingsassistenten Peter är mycket tyst under den gruppintervju där vi bland annat talar om manlig och kvinnlig behandlingspersonal. I den individuella intervjun med Peter som följer efter gruppintervjun tar Peter själv upp den frustration han känner över könsroller på institutionen.

\section{Excerpt 3.}

Deltagare: Peter, behandlingsassistent (P), Carolina Överlien (C), och Margareta Hydén (M)

\begin{tabular}{lll}
\hline I & P & $\begin{array}{l}\text { Vad jag tror att man vill i första läget } \\
\text { skydda många barn (.) från män i första } \\
\text { läget va }\end{array}$ \\
\hline 2 & $M$ & mm \\
\hline 3 & $P$ & $\begin{array}{l}\text { Och då är det väldigt svårt för män (.) } \\
\text { att komma in (.) redan från start }\end{array}$ \\
\hline
\end{tabular}

\begin{tabular}{|c|c|c|}
\hline & M & $\mathrm{Ja}$ \\
\hline 5 & $P$ & $\begin{array}{l}\text { Mm (.) att börja jobba med de här } \\
\text { barnen som jag anser är (.) är (.) det } \\
\text { lika viktigt att jobba med sexuella } \\
\text { övergreppet (.) som att jobba med } \\
\text { mansbilden }\end{array}$ \\
\hline 6 & M & $\mathrm{mm}$ \\
\hline 7 & $P$ & $\begin{array}{l}\text { Mm (.) och det tycker jag är en väldig } \\
\text { stor svårighet för då blir liksom alla } \\
\text { män dragna över samma linje (.) alla } \\
\text { män är så här och det har jag ju sett } \\
\text { under alla år att (.) när den attityden } \\
\text { kommer fram kan det bli väldigt svårt } \\
\text { (.) att jobba och skapa relationer }\end{array}$ \\
\hline 8 & $M$ & $\mathrm{Ja}$ \\
\hline
\end{tabular}

Peter menar att "man« (som jag tolkar som »kvinnlig behandlingspersonal«) först och främst vill skydda de omhändertagna tjejerna från män, och framför allt »jobba med sexuella övergreppet». I en sådan situation menar Peter att »det är väldigt svårt för män (.) att komma in«. Han menar att det är lika viktigt att "jobba med mansbilden", som det sexuella övergreppet. I det arbetet blir "alla män dragna över samma linje», d.v.s. alla män blir sedda som potentiella förövare. I ett sådant arbetsklimat blir det »väldigt svårt (.) att jobba och skapa relationer«, menar Peter.

Även Mattsson (2005) fann i sin studie om manlig och kvinnlig personal på två institutioner som bedriver missbrukarvård, att personalen har stereotypa könsföreställningar som ligger till grund för behandlingsarbetet. Manlig och kvinnlig personal har olika roller utifrån deras kön, kvinnor ska vara förebilder och männen ska hålla distans såsom "goda» män. Mattsson menar att dessa roller begränsar både kvinnlig och manlig behandlingspersonal i deras arbete. 


\section{Att tala om omhändertagna flickors sexualitet}

När en ung kvinna kommer till Sommargården utgår personalen ifrån att hon har varit utsatt för sexuella övergrepp. En av de manliga behandlingsassistenterna menar att "de har alla varit utsatta på ett eller annat sättu. Först och främst är de alltså offer för manlig sexualitet, men de anses också ha en destruktiv sexualitet, ofta som ett resultat av de övergrepp de varit utsatta för, och denna sexualitet behöver omdefinieras. En destruktiv, utåtagerande sexualitet behöver omskapas för att sedan kunna byggas upp på nytt. Tiden på Sommargården skulle därför användas som en "time-out" från sexualiteten som sådan. De omhändertagna unga kvinnorna ansågs behöva "vila» från sexualitet. De fick därför inte ha romantiska/ sexuella relationer med varandra, och man uppmuntrade heller inte relationer med andra utanför institutionen. Som ett led i den strävan så tilläts inga filtar eller plädar i tv-sofforna. För att använda Fines (1988) ord, så rådde en missing discourse of desire, vid institutionen. Inom ramen för tvångsomhändertagande definieras alla sexuella handlingar som sexuella övergrepp, eftersom kategorin "lust» var otänkbar. Manlig sexualitet ansågs ha negativa eller skadliga implikationer för de unga kvinnorna.

\section{Att omdefiniera unga kvinnor till sexuellt avvikande "små prinsessor"}

Behandlingsassistenten Nils fick frågan vad han ansåg om de omhändertagna unga kvin- nornas behov av närhet. Han valde då att berätta om Anna, en av de yngsta på institutionen, och hur han tvekade att vara nära henne eftersom hon ansågs "fixerad av sex».

\section{Excerpt 4.}

Deltagare: Nils, behandlingsassisten (N), och Carolina Överlien (C).

\begin{tabular}{|c|c|}
\hline I N & $\begin{array}{l}\text { Många av flickorna kommer väldigt } \\
\text { ofta och ställer sig väldigt nära mig och } \\
\text { vill hålla om mig och så vidare och så } \\
\text { vidare (.) Anna Andersson är ju en } \\
\text { person som varit väldigt mycket sån (.) } \\
\text { men utifrån dom telefonsamtal som } \\
\text { hela tiden anspelar på sex (.) utifrån } \\
\text { hennes situation i skolan som väldigt } \\
\text { mycket handlar om sex (.) alla hennes } \\
\text { för hon är ju någonstans i kiss- och } \\
\text { bajsåldern alltså (.) och hela tiden är } \\
\text { det detta som är det centrala i hennes } \\
\text { hjärna (.) hon någonstans fått mig att } \\
\text { (.) ja (.) ta bort henne på ett fint sätt då } \\
\text { va (.) när hon kommer = }\end{array}$ \\
\hline $2 C$ & När hon kommer nära \\
\hline $3 \mathrm{~N}$ & $\begin{array}{l}\text { Ja visst när hon kom i början så kunde } \\
\text { jag låta henne stå och hänga så och } \\
\text { hålla armen runt mig så va och hon } \\
\text { skulle sitta väldigt nära och så och det } \\
\text { har jag inte bekymmer med (.) men } \\
\text { utifrån att jag idag har kunnat se att } \\
\text { hon nästan blivit mer och mer (.) cen- } \\
\text { tralt i det det är liksom det som finns } \\
\text { i hennes huvud hela tiden (.) så har } \\
\text { jag tyckt att på något sätt så finns det } \\
\text { kanske andra saker än bara detta och } \\
\text { det blir ju barnsligt och larvigt till slut. }\end{array}$ \\
\hline
\end{tabular}

Enligt Nils så var Annas hjärna ständigt fokuserad på sex, men inte i en vuxen bemärkelse, utan på ett omoget barnsligt sätt. Allt från hennes telefonsamtal till beteende i skolan förstods utifrån hennes barnsliga upptagenhet av sexualitet. 
Anna tycker om att stå nära Nils, att lägga sin arm runt hans rygg och sitta bredvid honom. Nils tolkning av detta är att "hon är någonstans i kiss- och bajsåldern alltså» och att detta blir »barnsligt och larvigt till slut». Det finns uppenbara motsägelser i hans utsaga. Om han endast såg henne som ett oskyldigt barn skulle han inte behöva oroas av att hon vill sitta nära honom. Nils tveksamhet att vara nära Anna visar att han, trots hans upprepade argument om att hon är »barnslig", har problem med att till fullo placera Anna i kategorin "oskyldigt barn«. När hon vill komma nära försöker han »ta bort henne på ett fint sätt då va" för att undvika att anspela på vad som »är det centrala i hennes hjärna». Anna definieras som ett barn men samtidigt som sexuellt destruktiv och därför omöjlig att vidröra. Att dra slutsatsen att Annas beteende är "barnsligt och larvigt" är att reducera Anna, att se hennes kropp som hennes öde snarare än hennes situation (Moi 1999).

Följande exempel visar att frågor som rör sexualitet på Sommargården är ännu mer komplexa än det som föregående exempel visar. Behandlingsassistenten Thomas talar i en individuell intervju om hur manlig personal är försiktiga i kontakten med de omhändertagna unga kvinnorna, för att deras handlingar inte ska missförstås som sexuella. Ett eventuellt missförstånd kan vändas mot den manliga personalen, något som Thomas menar har skett på institutionen förut. Jag introducerar då en diskussion om ett samtal mellan honom och Charlotta, en ung kvinna som bor på hans avdelning, som ägde rum några dagar tidigare. Rummet där sam- talet mellan Charlotta och Thomas ägde rum (och där jag som forskare också fanns närvarande) har stora glasfönster som vetter ut mot ingången till avdelningen. Det ger en typ av Panopticon-utsikt över avdelningen som ger möjlighet till bevakning och kontroll (se Foucault 1977). Alla inne på avdelningen kan alltså se vad som sker i detta rum. Personalen på avdelningen misstänker att Charlotta har gjort ett självmordsförsök under natten, och det är Thomas uppgift att tala med henne om hur hon mår.

\section{Excerpt 5.}

Deltagare: Thomas, behandlingsassistent (T), och Carolina Överlien (C).

\begin{tabular}{|c|c|c|}
\hline I & C & $\begin{array}{l}\text { För jag tänkte på en sån situation } \\
\text { som just du var inblandad i när när } \\
\text { den där dan när Charlotta var så } \\
\text { ledsen och satt på kontoret och du } \\
\text { satt bakom= }\end{array}$ \\
\hline 2 & $\top$ & Ja just det= \\
\hline 3 & C & $\begin{array}{l}\text { Och hon pratade om att hon inte ville } \\
\text { (.) leva och tårarna rann }\end{array}$ \\
\hline 4 & $\mathrm{~T}$ & $\mathrm{Mm}$ \\
\hline 5 & C & $\begin{array}{l}\text { Hon var ledsen och så (.) jag tänkte } \\
\text { på i den situationen du valde att sitta } \\
\text { kvar på andra sidan skrivbordet ni } \\
\text { hade skrivbordet emellan er så att } \\
\text { säga (.) var det någonting som du } \\
\text { (.) en genomtänkt strategi från din } \\
\text { sida att inte gå runt och ta i henne } \\
\text { lägga armen runt henne och säga lilla } \\
\text { gumman liksom så (.) det ska nog gå } \\
\text { bra det här eller förstår du }\end{array}$ \\
\hline 6 & $\mathrm{~T}$ & Ja jag förstår \\
\hline 7 & C & $\begin{array}{l}\text { Jag funderade lite på vad du tänkte i } \\
\text { den situationen }\end{array}$ \\
\hline
\end{tabular}




\begin{tabular}{|c|c|c|}
\hline 8 & $\mathrm{~T}$ & $\begin{array}{l}\text { Jag tror det är enklare om man har } \\
\text { diskussionen på den nivån som det } \\
\text { ändå var (.) det är enklare om man } \\
\text { sitter en bit ifrån annars blir det (.) } \\
\text { lite (.) kanske pluttenuttigt (.) och } \\
\text { det är enklare om man sitter och } \\
\text { diskuterar för annars blir det mer (.) } \\
\text { eh det är klart att det blir känslolad- } \\
\text { dat i alla fall }\end{array}$ \\
\hline 9 & $C$ & $\mathrm{Mm}$ \\
\hline 10 & $\mathrm{~T}$ & $\begin{array}{l}\text { För henne är det kanske (.) ja jag vet } \\
\text { inte riktigt (.) men jag känner att det } \\
\text { är (.) det var jag ville sitta så eller det } \\
\text { blev så }\end{array}$ \\
\hline 11 & $C$ & Ja (.) ja \\
\hline 12 & $\top$ & $\begin{array}{l}\text { Men nästa gång kanske sätter sig } \\
\text { jämte henne (.) mer (.) men då } \\
\text { är det enklare hennes tankar kan } \\
\text { skena iväg på något annat och hon } \\
\text { kanske (.) känner att hon vill ha en } \\
\text { kram som stöttning eller vad som } \\
\text { helst men (.) det kan bli så fel också } \\
\text { tror jag }\end{array}$ \\
\hline
\end{tabular}

Situationen vi talar om, samtalet mellan Charlotta och Thomas, var spänd och emotionellt laddad, då Charlotta grät och berättade hur hon längtade efter sin mamma. Trots det väljer Thomas att sitta kvar på andra sidan skrivbordet. Hans val var »enklare« eftersom alla andra valmöjligheter hade blivit mer emotionellt laddade (tur 8).

Det finns flera olika sätt att förstå denna händelse. Thomas handling (eller snarare brist på handling) kan förstås som ett professionellt val, eftersom alla fysiska handlingar (såsom att lägga armen runt Charlotta) i denna institutionella kontext skulle kunna uppfattas som sexuella, och därför otänkbara. Dessutom är alla mina, Thomas, och Charlottas handlingar synliga för de andra som vistas på avdelningen.
Thomas professionalitet är därmed "on display». Thomas handlingar kan därför förstås som en reflektion av de rådande institutionella normerna på Sommargården. Thomas menar att det finns risk för att hans eventuella handlingar skulle uppfattas av Charlotta som "pluttenuttigt» (tolkat av mig som »sött» och »ofarligt»), men i själva verket skulle det kunna bli mycket allvarligare än så. I värsta fall hade en spontan reaktion såsom en kram kunnat kosta en manlig personal hans jobb, eller åtminstone gett upphov till en allvarlig diskussion bland personalen.

En annan tolkning av ovanstående situation rör synen på de omhändertagna unga kvinnorna som sexuellt problematiska. Thomas rättfärdigar sitt sätt med argumentet att »hennes tankar kan skena iväg på något annat", om han skulle erbjuda en fysisk handling som tröst. Ansvaret för det som skulle kunna ske placeras på den unga kvinnan. Det är hennes tankar som skulle kunna "skena iväg på något annat", hon skulle kunna tolka hans till fullo tröstande handlingar på ett sätt som inte var hans mening, och situationen skulle därmed kunna "bli så fel«. Charlotta förstås som en ung kvinna med en destruktiv sexualitet, eftersom hon kan uppfatta en tröstande kram som en sexuell invit.

I följande exempel intervjuar jag behandlingsassistenten Tina, som berättar om en ung kvinna som gick in i vardagsrummet naken. Både manliga och kvinnliga behandlingsassistenter var närvarande vid tillfället. 


\section{Excerpt 6.}

Deltagare: Tina, behandlingsassistent (T), och Carolina Överlien (C).

\begin{tabular}{lll}
\hline I & T & Jag vet en annan flicka som vi hade (.) \\
& & $\begin{array}{l}\text { som var } 17 \text { eller I } 8 \text { år (.) hon tog av sig } \\
\text { var hon } 4-5 \text { år }\end{array}$ \\
\hline 2 & C & jaja \\
\hline 3 & T & Hon var alltså mannekänga för pappa \\
\hline 4 & C & Mm \\
\hline 5 & T & Hon ville få bekräftelsen \\
\hline 6 & C & mm \\
\hline 7 & T & Hon ville vara lilla prinsessan \\
\hline 8 & C & Så det var inget sexuellt utspel då \\
\hline 9 & T & Nej (.) det var mer se hur söt jag är så \\
\hline
\end{tabular}

En 17-18-årig ung kvinna går in naken i ett vardagsrum, och blir definierad av den närvarande personalen som en 4-5-årig flicka, en liten prinsessa som vill vara fin inför pappa, och inte som en ung kvinna som gör en sexuell handling. För mig som forskare som hade tillbringat flera veckor i 14-20-åriga unga kvinnors närhet vars primära mål var att "göra kvinnau, så var denna omdefiniering av den unga kvinnan i fråga en smula överraskande.

När man placerar in Tinas tolkning av den unga kvinnans handlande som en lekfull, oskyldig handling mellan far och dotter, i en institutionell kontext, blir Tinas berättelse mer förståelig. Den rådande metadiskursen vid Sommargården om sexualitet, och den behandlingsideologi som genomsyrade intervjuerna, var att alla unga kvinnor skulle förstås som barn. Myten om det icke-sexuella barnet diskuteras bl.a. av Walkerdine (1997) som talar om spänningsfältet mellan vår kulturella förståelse av det icke-sexuella barnet och samhällets exploaterande vuxna sexualitet, framförallt representerat av medias sexuella blick. På samma sätt talar personalen på Sommargården om de unga kvinnorna som korrumperade av destruktiv manlig sexualitet. Tiden på Sommargården var en tid för vila från denna sexualitet, och alla implicita och explicita sexuella handlingar som de unga kvinnorna tog del av skulle förstås och tolkas i ljuset av detta. Genom denna omdefiniering och regression av de unga kvinnorna skulle deras destruktiva sexualitet kunna omskapas till en "normal" hälsosam sexualitet. De unga kvinnorna skulle få möjlighet att »börja från början igen«. Genom att starta om igen kan nya värderingar och alternativa beteenden läras in. På institutionen sker en normaliserande praktik som har som syfte att fostra och göra det avvikande normalt (cf Mattsson 2005). Hur de unga kvinnorna skulle ta del av denna nya och sunda normala sexualitet blev dock inte klart under mina månader på Sommargården, eftersom ämnet sexualitet oftast undveks. Genom att ge möjlighet till "vila" ansågs problemet löst.

Även Andersson $(1998,2000)$ fann i sin studie om unga kvinnor på institution att de primärt sågs som offer av personalen, och att deras sexualitet talades om som något problematiskt och destruktivt. När unga kvinnor uppfattas som "promiskuösa" och som sexuellt „icke-normala», så handlar det om moral. De bryter med de samhälleliga normer om vad som är acceptabelt och ej för en ung kvinna. Hennum (1999) har studerat samspelet mellan ungdomar och personal på ett ungdomshem, och menar 
att ndet moraliska systemet inkluderar det behandlande systemet och är överordnat det. Med andra ord arbetar personalen med att förvalta en bestämd samhällsmoral eller moraliska koder, snarare än behandlar" (s. 79 , min översättning). Det icke-normala ska göras normalt och det dysfunktionella funktionellt. Och »de som inte låter sig förändras eller normaliseras silas ut ur systemet, om de inte har rymt innan dess", menar Hennum (1999 s. 79, min översättning).

\section{Slutdiskussion}

Ambitionen med denna artikel är att visa hur sexuell identitet skapas och hur frågan om sexualitet genomsyrar det vardagliga arbetet på Sommargården. Jag har också velat visa hur personalen talar om de unga kvinnornas sexualitet. Jag har visat att personalen talar om de omhändertagna flickorna på två olika sätt; som asexuella barn och som offer för sexuella övergrepp. Dock visar exemplet med Nils och Anna (excerpt 4) att de unga kvinnorna samtidigt ses som sexuellt destruktiva och avvikande, och därmed inte blir möjliga att vidröra. Roten till denna icke-normala sexualitet menar personalen finns i de sexuella övergrepp som de unga kvinnorna blivit utsatta för.

Varför omdefinierar personalen de unga kvinnorna till 4-5-åriga barn? Det finns åtminstone två möjliga svar på den frågan. Genom att tala om de unga kvinnorna som barn försöker personalen skapa en arena fri från sexuell identitet. Sex blir till en icke-fråga. Faktum är att Sommargården byggdes endast för unga kvinnor med ett av målen att undvika denna svåra fråga.
Manlig personal, ofta endast några få år äldre än de unga kvinnorna själva, ses som ett möjligt hot och bör därför undvika all fysiskt kontakt med de unga kvinnorna. De unga kvinnorna är på så sätt skyddade från en destruktiv, explosiv manlig sexualitet, och de manliga behandlingsassistenterna skyddas från de unga kvinnornas icke-normala sexualitet. I en arbetsmiljö där manlig personal bor med tvångsomhändertagna unga kvinnor dygnet runt, kan konstruktionen av unga kvinnor som asexuella barn vara den enda möjliga lösningen på ett komplext institutionellt dilemma.

En annan möjlig analys jag har presenterat i denna artikel är att anledningen till att personalen omdefinierar de unga kvinnorna till 4-5-åriga barn, är att de vill ge dem möjligheten att "börja om igen". Personalen ser det som deras ansvar att hjälpa de unga kvinnorna att återfå kontrollen över sina kroppar och sin sexualitet. Genom att tala om dem som barn och att ordinera "vila", så ges de unga kvinnorna möjlighet att återbygga en hälsosam, normal sexualitet. Genom att börja om igen kan nya normer läras och alternativa beteenden övas in. I metadiskursen om de unga kvinnorna som barn och som offer för sexuella övergrepp ryms inte diskurser om de unga kvinnorna som sexuellt handlande subjekt. Begreppet "lust" är en icke-existerande kategori.

Kön, sexuell identitet, normalitet och moral är frågor som sällan diskuteras i relation till begreppet institution. Som Hennum (1999) betonar är ungdomsinstitutioner slutna samhällen, i den bemärkelsen att omvärlden har begränsad insyn och det råder en sträng social kontroll. I ett sådant samhälle är flexibiliteten begränsad 
och det finns tydliga gränser för det som anses normalt. Gränssättning legitimeras med ungdomarnas psykologiska behov, snarare än som ett uttryck för moral. Bemötandet av ungdomarna som sexuella varelser bygger på ett heteronormativt tänkande och stereotypa könsföreställningar. I denna Goffmanska totala institution kan könsnormer bli till kontroll och disciplin och den skapade sexuella identiteten den överordnade organisatoriska principen.

Jag menar därför att vi behöver bättre kunskap på en rad områden som rör omhändertagande av unga i Sverige idag. Liksom Lundström och Sallnäs (2003) menar jag att vi behöver en bättre systematisk kunskap om vilka implicita och explicita kriterier som används vid ett beslut om omhänder- tagande och om de könsrelaterade mönster som framträder. Även Socialstyrelsens rapport (2004) Jämställd socialtjänst? Könsperspektiv på socialtiänsten efterlyser bättre systematisk kunskap där frågor som rör pojkars och flickors sexualitet i relation till placeringar utanför hemmet, är särskilt viktiga att få belysta. Med en ökande grupp unga kvinnor på särskilda ungdomshem krävs en ökad kunskap om skapandet av sexuell identitet och dess betydelse i institutionens vardag.

\section{Transkriptionsnyckel}

(.) paus som är mindre än en sekund

fet ord som är betonat

$=\quad$ överlappande tal

\section{Referenser}

Andersson, Berit (1998) Ett \$12-hem för flickor. Omdefinitioner $i$ ungdomsvården. SiS Rapport nr 2, 1998. Stockholm: SiS.

Andersson, Berit (2000) »De besvärliga flickorna - ungdomshemmets disciplin ur ett genusperspektiv.. I Sahlin \& Åkerström (red.) Det lokala vaildet: om rädsla, rasism och social kontroll. Stockholm: Liber.

Andersson, Christina (1993) The children of Maria. Adolescent Substance Abusers, their Families and Schooling. Uppsala Studies in Education 46. Stockholm: Almqvist \& Wiksell International. Diss.

Andersson, Christina (1996) "Om struliga flickor - beteende och bemötande." I Bengt-Åke Armelius (red.) Vård av ungdomar med sociala problem - en forskningsöversikt. Stockholm: Statens Institutionsstyrelse och Liber Utbildning $\mathrm{AB}$.

Andersson, Gunvor (2005) „Family relations, adjustment and well-being in a longitudinal study of children in care." Child \& Family Social Work, 10(1), s. 43-56.

Baines, M. \& Alder, C. (1996) "Are girls more difficult to work with? Youth workers' perspectives in juvenile justice and related areas." Crime and Delinquency, 42, s. 467-485.

Boylan, Jane \& Ing, Pauline (2005) "'Seen but not heard'- young people's experience of advocacy." International Journal of Social Welfare, 14(1), s. 2-12.

Cederborg, Ann-Christin \& Karlsson, Yvonne (2001) "Omhändertagande med barnets perspektiv." Socialvetenskaplig tidskrift. 3, s. 163179.

Chesney-Lind, Meda \& Shelden, Randall G. (1998) Girls, delinquency, and juvenile justice. Belmont, CA.: Wadsworth.

Ericsson, Kersti (1997) Drift og dyd. Kontrollen av jenter påfemtitallet. Oslo: Pax. 
Fine, Michelle (1988) „Sexuality, Schooling, and Adolescent Females: The Missing Discourse of Desire." Harvard Educational Review. Vol 58 nr 1, s. 29-53.

Foucault, Michel (1977) Discipline and Punish: the Birth of the Prison. London: Allen Lane.

Goffman, Erwing (1983) Totala institutioner: fyra essäer om anstaltslivets sociala villkor. Stockholm: Rabén \& Sjögren.

Hegna, Kristinn \& Pedersen, Willy (2005) Sex for overlevelse eller skyggebilder av kjärlighet. Ungdom under 18 år som selger seksuelle tjenester. Rapport 5/2005. Oslo: Norsk institutt for forskning om uppvekst, velferd og aldring.

Hennum, Nicole (1999) „Hvordan forstår institusjonen ungdom?" Barn Nr. 1, s. 70-82.

Hilte, Mats \& Claezon, Ingrid (2005) Flickor och pojkar på institution - ett könsperspektiv på vården av ungdomar. Skriftserie 2005:4. Stockholm: Stiftelsen Allmänna Barnhuset.

Hudson, Barbara (1989) „A Comparison of Recent Developments in the English and French Juvenile Justice Systems." I Maureen Cain (red) Growing Up Good. Policing and Behavior of Girls in Europe. London: Sage.

Hydén, Margareta \& Överlien, Carolina (2005) "Applying Narrative Analysis to the Process of Confirming or Disregarding Cases of Suspected Sexual Abuse». Child and Family Social Work, 10, s. 57-65.

Hydén, Margareta (2000) „Forskingsintervjun som relationell praktik. I I Hanne Haavind (red.) Kön och tolkning. Stockholm: Natur och kultur.

Jonsson, Gustav (1977) Flickor på glid: en studie $i$ kvinnoförtryck. Stockholm: Tiden.

Knutsdotter Vanström Linda, Palmgren Langlet Ann-Christine \& Björk Stina (2005) SiS statistik år 2004. Allmän SiS-rapport 2005:7. Stockholm: Statens Institutions Styrelse.

Levin, Claes (1997) Ungdomar i tvångsvård. Råbyundersökningen 94. Lund: Meddelanden från Socialhögskolan 1997:9.

Lundström, Tommy \& Sallnäs, Marie (2003) „Klass, kön och etnicitet i den sociala barnavården." Socialvetenskaplig tidskrift 2-3, s. 193-213.

Mattsson, Tina (2005) I viljan att göra det normala: en kritisk studie av genusperspektivet i missbrukarvården. Malmö: Égalité.

Mattsson, Titti (2002) Barnet och rättsprocessen: rättssäkerhet, integritetsskydd och autonomi $i$ samband med beslut om tvångsvård. Lund: Juristförlaget.

Moi, Toril (1999) What Is a Woman? And Other Essays. Oxford: Oxford University Press.

Morgan, David (1996) "Focus Groups." Annual Review of Sociology. Vol 22 s. 129-152.

Ochs, Ellinore (1979) "Transcription as Theory». I Ellinore Ochs \& Bambi Schieffelin (red.) Developmental Pragmatics. New York: Academic Press.

Odem, Mary. (1995) Delinquent Daughters. Protecting and Policing Adolescent Female Sexuality in the United States 1885-1920. Chapel Hill, NC: The University of North Carolina Press.

Osvaldsson, K. (2002) Talking Trouble. Institutionality and Identity in a Youth Detention Home. (Ak. avh.). Linköping: Linköping Studies in Art and Science.

Riessman, Catherine Kohler (1997) „Berätta, transkribera, analysera. En metodologisk diskussion om personliga berättelser i samhällsvetenskapen." I Lars-Christer Hydén \& Margareta Hydén (red.) Att studera berättelser. Samhällsvetenskapliga och medicinska perspektiv. Stockholm: Liber.

Robinson, Robin A. (1994) „Private pain and public behaviors: sexual abuse and delinquent girls" I Cathrine Kohler Riessman (red.) Qualitative Studies in Social Work Research. Thousand Oaks, CA.: Sage.

Sallnäs, Marie (2000) Barnavårdens institutioner - framväxt, ideologi och struktur. (Avh.) Stockholm: Stockholms universitet.

Sallnäs Marie, Vinnerljung Bo, \& Westermark Kyhle Pia (2004) "Breakdown of teenage placements in Swedish foster and residential care." Child and Family Social Work 9 (2), s. 141-152.

Schlytter, Astrid (1999) Kön och juridik $i$ socialt arbete: tillämpningen av $3 \S L V U$ på länsrättsnivå. Lund: Studentlitteratur.

Schlytter, Astrid (2000) "Kvinnokroppen som text." Socialvetenskaplig tidskrift 1-2: s. 109-119.

Carolina Överlien: Institutionen som arena för skapandet av sexuell identitet. 
Shoemaker,Donald(1984) Theories of Delinquency.

An Examination of Explanations of Delinquent

Behavior. NY: Oxford University Press.

SiS (2005) "Den svåra balansgången." Sistone nr 3.

Socialstyrelsen (2000) Barn och unga - Insatser år 2000. Dokumenttyp: Statistik.

Socialstyrelsen (2004) Jämställd socialtjänst?

Könsperspektiv på socialtjänsten. Dokument-

typ: Uppföljningar och utvärderingar.

Socialstyrelsen (2005) Barn och unga - Insatser år 2004. Stockholm.

Socialstyrelsen (2006a) Individ- och familjeomsorg

- Lägesrapport 2005. Stockholm.
Socialstyrelsen(2006b) Social rapport 2006. Stockholm.

Sundkvist, Maria (1994) De vanartade barnen. Mötet mellan barn föräldrar och Norrköpings barnavairdsnämnd 1903-1925. Falkenberg: Hjelms.

Sunesson, Sune (1992) „Problem och problematiseringar." Nordiskt Socialt Arbeid, 2, s. 57-69.

Walkerdine, Valerie (1997) Daddy's Girl. Young Girls and Popular Culture. London: Macmillian Press Ltd.

Överlien, Carolina \& Hydén, Margareta (2003) "Hon framstår som en ärlig tjej helt enkelt.»FAS konferenspaper.

\section{Summary}

\section{The institution as an arena for the construction of sexual identity: Talk at a youth detention home}

This article examines how staff members at a Swedish detention home talk about sexuality, both in regard to each other and in regard to the young women placed there. The analysis shows that, although the staff try to create an arena free from issues of sexuality, sexual identity is used as an organizational principle at the institution. Female staff members are used as "gate keepers" to protect the young women from destructive male sexuality, and the male staff from the dysfunctional sexuality of the young women. The analysis furthermore shows that staff members at the detention home construct the young women as sexually innocent. Why do the staff members redefine young women as children and what are the implications of that? The analysis in this paper presents two possible answers to the first question. By talking about the young women as child- ren, the staff can be seen as constructing a zone free from sexuality. Sex becomes a non-issue. In fact, the detention home was built only for young women, and has always been an all-female institution, precisely with the intention of avoiding the problematic issue of sexuality. Male staff, often only a few years older than the young women, are seen as a potential threat to the young women. They are asked to keep all bodily contact to a minimum, and female staff take on the role of controllers of male staff and their conduct. A second explanation is that the staff want to give the young women a chance to "start over again", to help the young women "rebuild" a healthy, "normal" sexuality and to replace their dysfunctional and inappropriate sexuality. By starting over, new norms can be learned and alternative behaviour modelled. 